\title{
Creating Additional Benefits in Enterprises by Private Equity Funds: Results of Researches
}

\author{
Ilona Falat-Kilijanska \\ Wroclaw University of Economics, Wroclaw, Poland
}

\begin{abstract}
The objective of this paper is non-financial aspects of private equity and venture capital investments and their impact on companies. Private equity funds providing capital to companies significantly increase their growth opportunities. The paper presents author's own studies of the private equity investment influence for the enterprise activity. Comparing venture-backed firms and others, it shows that venture-backed companies patent more than other firms and their ideas are higher technological and economic values. The vast majority of polish managers believe their company would not have existed or would have grown less rapidly without venture capital. Respondents also believe that venture capital funding encouraged employment, investment, R\&D (research and development) spending, and export. An important source of empirical data is performed by author's own surveys and interviews with representatives of shareholding companies, as well as private equity fund managers. The period of this research is between 1998 and 2012. The study used several research methods: a descriptive method, the method of comparative analysis, the method of critical analysis, and synthesis applications.
\end{abstract}

Keywords: private equity, venture capital, financial investor

The growing importance of European private equity investments in enterprise development has been observed since 1995. The amounts invested in companies in their early stages of life, as well as in the mature ones have been gradually increasing. The annual level of investment in start-ups has grown almost fourfold (from 1.6 billion euro in 1998 to over six billion euro in $2008^{1}$ ). Within the same period, the share of funding mature entities in the private equity investment market was growing at an average annual rate of $36 \%$. By providing capital to companies, the private equity fund visibly enhances their growth. The study conducted by the author shows that the fund does not only provide the capital, but also brings many additional benefits, since/after becoming one of the major shareholders of a given company-its influence on the strategic decisions taken by the company's management, the direction of its development and the future ownership structure are quite considerable. The study is allowed to determine the private equity fund's role in establishing the market position of Polish companies. Therefore, the aim of this paper is to show the non-financial aspects of private equity investments and their impact on companies' activities.

The primary source of empirical data is author prepared surveys and interviews with both representatives

Corresponding author: Ilona Falat-Kilijanska, Ph.D., assistant professor, Department of Finance, Wroclaw University of Economics, Wroclaw, Poland; research fields: private equity and venture capital investments, financial markets, international finance, corporate finance and governance (M\&A). E-mail: i.falat-kilijanska@ue.wroc.pl.

${ }^{1}$ Between the years of 2009 and 2012, there was a decrease at the level of investment in the early stages-about three billion a year. 
of shareholding companies and private equity fund managers. The research covered the years from 2002 to 2012.

Several research methods were used in the study: the descriptive method, the comparative analysis method, the critical analysis method, and the synthesis of conclusions method. Moreover, analysis of the results obtained within the study and the statistical data analysis were conducted.

\section{Private Equity Funds}

Private equity funds are investments in the private equity market, aimed at obtaining earnings through capital gain. It is the purchase of shares of unlisted companies. To seek new development opportunities, private equity funds invest in both mature companies and new ventures. They are also often used in buyout, merger, and acquisition transactions. Private equity investments are obtained for the purposes of new product or technology development, increasing working capital, improving the balance or other major investment expenditures. A part of private equity is venture capital, i.e., investments made in the early stages of a business's life cycle for its start-up or expansion of its operations, usually in amounts smaller than in the case of private equity. These two terms are often used interchangeably (Fałat-Kilijańska, 2012, p. 93). For the purposes of this paper, the author uses the term "private equity" in its broadest sense ${ }^{2}$.

\section{The Role of the Private Equity Fund in Portfolio Companies: Research Results}

The main objective of private equity funds' investments is to make profit resulting from the increase in a portfolio company's value. The entity's capital resources are, of course, of key importance in this case. The conducted research has also confirmed this-94\% of all respondents stated that without the involvement of private equity capital, their companies would develop much slower or even cease to exist; also, many of the managers of young companies stated that without this type of support, their businesses would never have been founded at all (see Figure 1).

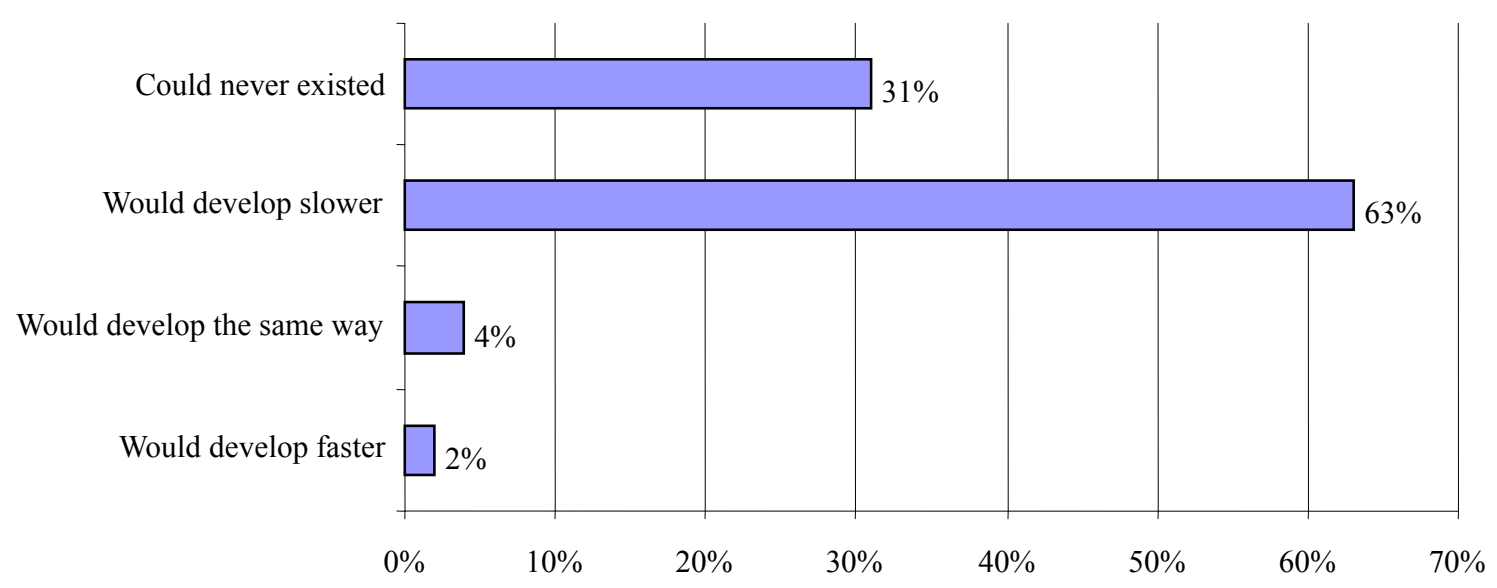

Figure 1. What would happen to your business if it had failed to obtain the fund as an investor? Source: own work based on a survey prepared by the author.

\footnotetext{
${ }^{2}$ The private equity and venture capital terms are defined differently in literature. The feature that helps to distinguish between them is the author's country of origin. Continental Europe, the United Kingdom, and the United States represent different approaches to private equity and venture capital investments. Although private equity investment is a concept broader than venture capital and the two may mean investments of very different character, these terms are often used interchangeably.
} 
The significance of private equity funds for the very existence of a given company and its degree of development are therefore enormous.

The literature on the issue mentions not only financial factors, but also marketing and intangible ones. Marketing factors consist in building customer loyalty, finding ways of acquiring new customers, winning new markets, gaining new channels of distribution, mergers and acquisitions, and globalisation. Intangible factors include the intellectual capital, the company's innovation capabilities, the brand's strength, internal communication, organisational culture, information systems, social reputation, and efficient logistics strategies (Zarzqdzanie wartościq firmy, 1999). When in search for factors affecting the creation of the value of a company operating in an economy largely based on knowledge, the management need to focus primarily on intangible factors. They should attach more importance to intellectual capital, information technology capital, and organisational capital.

Private equity investors are focused mainly on the financial aspects of their investments - they monitor the financial results and are often advisors in the area of the company's financial policy. It is frequent, however, that their contribution exceeds the financial scope and covers many different areas of the company's activity. As a co-owner, the fund is not interested in receiving regular interest on the invested capital, and the success of its investments is entirely dependent on the success of the company it invested in. The fund representatives must first of all get acquainted with the specifics of the shareholding enterprise's activity and actively participate in the management process. Due to low liquidity of private equity investments, during the investment period, investment partners follow two strategic objectives:

(1) Reducing the risk of adverse scenarios to the amount of the capital invested in the project;

(2) The "Capital Plus" concept, i.e., maximisation of the value of the company generating future capital gains ${ }^{3}$.

Based on the "Capital Plus" principle, the fund provides the company not only with the capital, but also various additional benefits constituting the "Plus" factor.

To specify what type of investor and given private equity fund is, the most important is to determine the degree to which the fund influences the company's current decisions (see Table 1). After signing the agreement and providing the company with the capital, the several-year period of cooperation is commenced. The fund is represented by one or more of "its own" people in the supervisory board. This allows the fund to monitor the company's current activities and the results it achieved. Moreover, the fund advises the management board on strategic issues, thus supporting the management with its knowledge and experience. Theoretically then, the fund does not participate directly in the management of a portfolio company, and its activities are often limited to provide the assistance of experts in such fields as finance, strategy, marketing, or human resources policy. Practice shows, however, that private equity investors can be divided into three types, depending on the level of their involvement in the company's management processes: hands-on funds, hands-off funds, and reactive funds.

Most often, hands-on participation in the management of a portfolio company is practiced by funds when they invest in the early stages of the company's development, whereas the other two approaches are applied in the mature stages of its life cycle. Hands-on fund managers devote a great deal of time to analysis and due

\footnotetext{
3 The “Capital Plus' concept was formed by Professor Klaus Nathusis in “Adding Value to Investment”, Entrepreneurship Education Course, Module 7, EVCA, Zavantem, Belgium, 2002. Retrieved from http://www.evca.com.
} 
diligence of the company, assessing the quality of the management staff. Fund managers are more experienced in building and managing the value of a company; therefore, the investment happens if the fund representatives are convinced of the company management's ability to realise the presented plans.

Table 1

Types of Private Equity Funds Depending on the Degree of Their Involvement in a Portfolio Company's Management Processes

\begin{tabular}{|c|c|c|}
\hline Type of private equity & Degree of involvement & Scope of activity \\
\hline \multirow{4}{*}{ Hands-on } & \multirow{4}{*}{ Active } & Participation in the creation of the business \\
\hline & & Active partnership \\
\hline & & Numerous additional benefits \\
\hline & & Monitoring of investments \\
\hline \multirow{3}{*}{ Reactive } & \multirow{3}{*}{ Active } & Observing "over the shoulder" \\
\hline & & Additional benefits offered depending on the company's needs \\
\hline & & Monitoring of investments \\
\hline \multirow[t]{2}{*}{ Hands-off } & \multirow[t]{2}{*}{ Passive } & $\begin{array}{l}\text { Monitoring of investments in accordance with the investment } \\
\text { agreement }\end{array}$ \\
\hline & & Limited financial monitoring \\
\hline
\end{tabular}

Note. Source: Klaus (2002).

In the case of the reactive fund type, less time is spent on operational management of the shareholding company. Involvement in the development activities of the company consists in placing its representative in the company's supervisory board, observing the work of the management board, monitoring the company's development process, above all, signalling and responding to negative deviations from financial targets specified in the business plan. If there occurs a disturbing situation, the fund becomes more active. The management board cooperating with a reactive fund has considerable freedom in building the company's growth and financial strategies. The actions of investment partners are focused on corporate governance in respect to reporting of financial statements (monthly and quarterly), recruiting key managers for the company and obtaining new sources of company financing (should such a need arise).

Hands-off funds are actually quite rare. This kind of involvement consists in occasional contacts with the portfolio company. The fund does not have its representative in the supervisory board. The company's reporting is done on semi-annual or even annual basis, and the monitoring of the company's finances is heavily limited. The primary goal is to focus on protecting the interests of the investors of the fund by monitoring the shareholders' rights defined in the investment agreement.

The author's study shows that Polish funds as investors usually adopt the reactive or hands-on approach - as evidenced by, e.g., the frequency of meetings between the company management and fund representatives (see Figure 2).

Frequency of contacts varies depending on the time that passed since the commencement of the investment period. In the initial period, fund representatives contact with the company management on a monthly basis, but as the investment period approaches the end, the frequency of meetings increases to typically once a week. The phase of a given company's life cycle does not directly relate to the frequency of contacts between the management and the investor. 


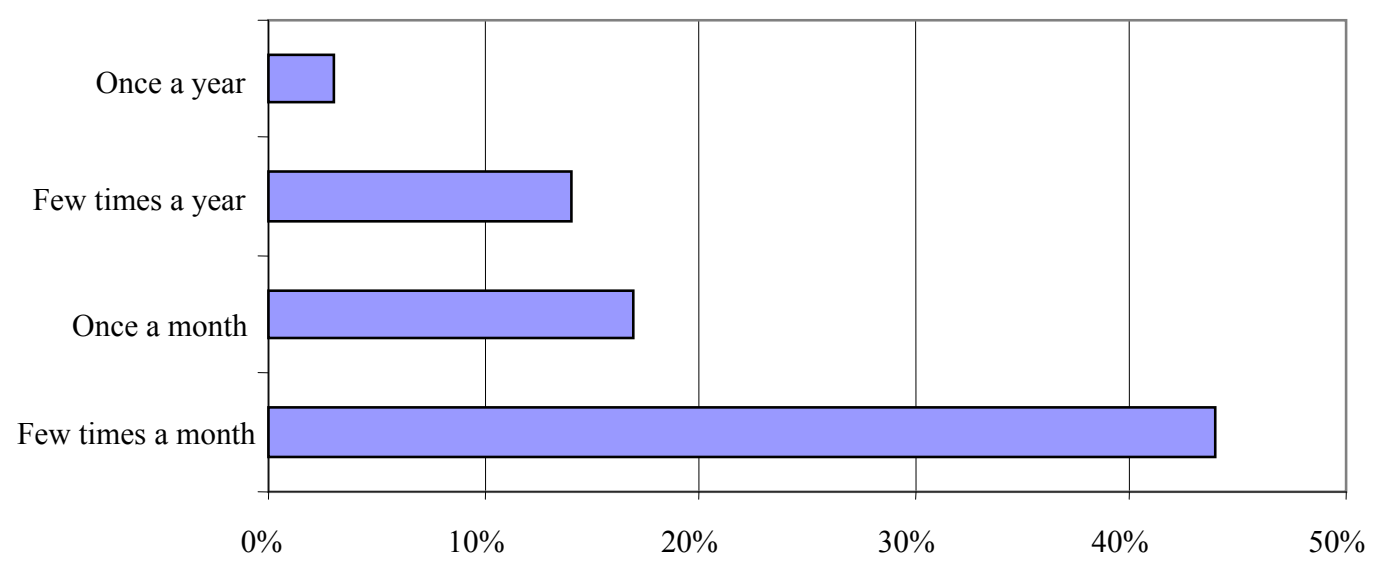

Figure 2. The frequency of contacts between the company and private equity fund representatives. Source: own work based on a survey prepared by the author.

In the second half of the 80 s of the 20th century, there were many studies on the role that the private equity fund plays in a portfolio company's activities. As a result, a list of additional benefits- that are brought by the fund in addition to the capital was created. For instance, on the basis of responses provided by 62 private equity funds, MacMillan and Kulow (1988, pp. 27-47) compiled a list of the most important activities performed by fund representatives in the companies:

(1) Having an active voice in the decisions made by the supervisory board and advising the management board;

(2) Assistance in obtaining alternative sources of financing;

(3) Mediation in dealing with investors interested in buying the company shares;

(4) Monitoring the company's financial results;

(5) Controlling the operational management.

By analysing the activities of 49 funds investing in the early-stage development companies, Gorman and Salman (1989, pp. 231-248) made a list of the most important additional benefits brought to companies by the investors:

(1) Assistance in obtaining additional funding;

(2) Strategic planning;

(3) Assistance in the recruitment of managerial staff;

(4) Operational planning;

(5) Assistance in gaining access to potential customers and suppliers;

(6) Design and implementation of a new payroll system.

Four other researchers-Rosentstein, Bruno, Bygrave, and Taylor (1989; 1993) studied the contribution of private equity representatives in the work of portfolio companies' supervisory boards. They analysed 162 companies from the high-tech industry which make use of the private equity capital. Company managers assessed the advice given to them by partners from the funds as more valuable than that given by other members of the supervisory board. The fund representatives' activity in maintaining corporate governance, dealing with investors, monitoring their operations, recruiting management board members, and solving current problems was defined as high. In addition, it was found that funds play a more important role in consultancy in the case of companies being in the early stages of development. 
In turn, Sapienza, Amason, and Manigart (1994, pp. 3-17) analysed the differences in the additional values among funds operating in several European countries (Great Britain, the Netherlands, and France) as compared with the United States. The most significant additional benefits associated with private equity capital in all the countries proved to be (in the same order): strategic, personnel, and operational consultancy. Research conducted two years later showed that the most important additional benefit was strategic consultancy, i.e., financial and business advising, as well as active participation in the supervisory board. The second on the list was the role of the fund representative as a mentor and trusted person of the president of the management board. Third on the list was the role of the fund as an intermediary in contacts with other companies or funds (Sapienza, Manigart, \& Vermeir, 1994, pp. 439-469).

The studies conducted by the author confirm the above-listed conclusions. Polish entrepreneurs find the non-financial aspects of the private equity investor to be of equal importance (see Figure 3). They simply believe that the possibility to obtain assistance in many different areas related to conducting business activity, the fund gains a huge advantage over other shareholders.

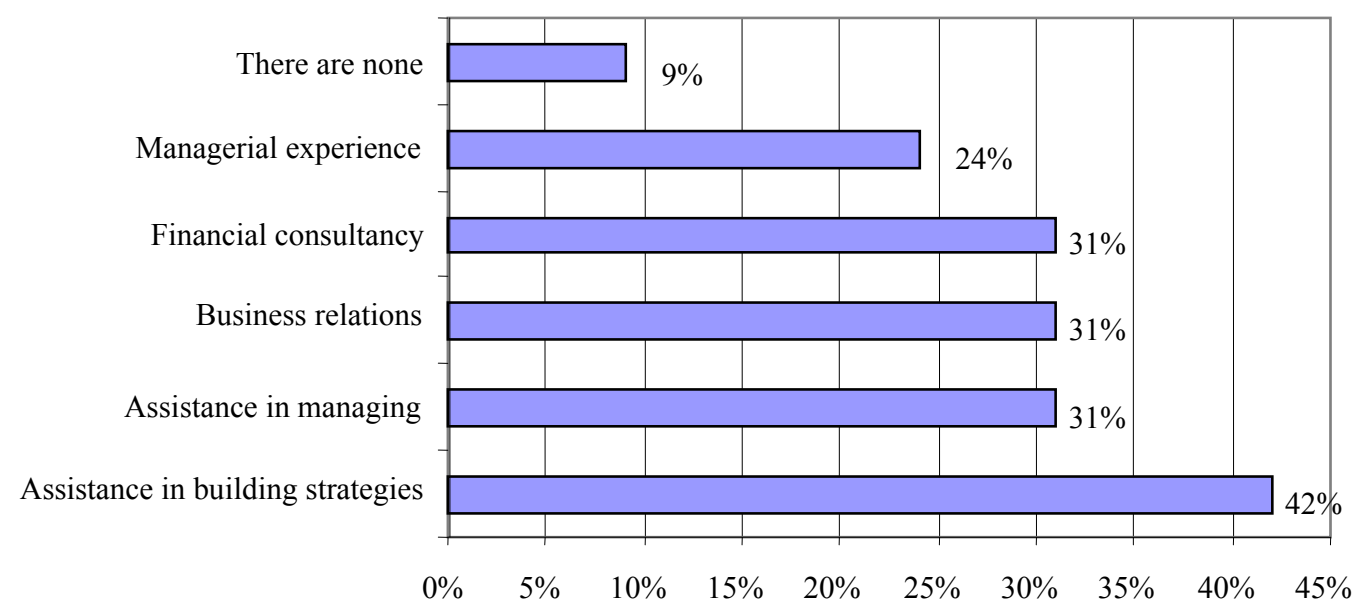

Figure 3. The main advantages of a private equity investor-apart from additional financing of a business's activity —indicated by Polish companies. Source: own work based on a survey prepared by the author.

In addition to close monitoring of the company's financial results, the management board can expect assistance in determining the primary objective of the activity or formulating the corporate strategy. The second on the list was: assistance in company management, financial consultancy, and numerous business relations of fund representatives. All these elements enable to focus on the company's core activities and achieve market success.

One example of a Polish company developing through acquisitions - which was possible only due to the involvement of the private equity fund-is Town \& City (now Ströer City Marketing Sp. z o.o.). In 1996, a fund managed by Innova Capital bought for $\$ 5$ million, $75 \%$ of the company, which at that time had a relatively small market share. Obtaining a new majority shareholder enabled the acquisition of two companies in the industry, making the company the largest player in its sector. The Polish market leadership position attracted the attention of foreign investors. In 1999, the company was sold to an Australian media mogul - Rupert Murdoch, and then became part of the News Outdoor Group. In 2012, it changed its owner once again, this time it went to the German Ströer Group. 
From the point of view of assessing private equity fund's role in the company's functioning, significant is also the distribution of answers to the question "Have you considered other ways of financing the activities of your business". As many as two thirds of respondents have not searched for other sources of capital (see Figure 4), this may indicate that at that moment, private equity capital was the best source of finance for company growth. Another reason may be the perfect adjustment of the fund's offer to the needs of companies that they established cooperation with. The cooperation alone proceeded without any major disruptions, especially in the first phase of mutual contacts between the fund and the company representatives.

A relatively small percentage of Polish entrepreneurs dissatisfied with the cooperation with private equity fund representatives confirm the thesis of effective realisation of the investment alone (see Figure 5). The survey results indicate that only $20 \%$ of company managers would definitely not re-establish contacts with any fund. After several years of doing business together, most company managers claim that the fund fully met their expectations.

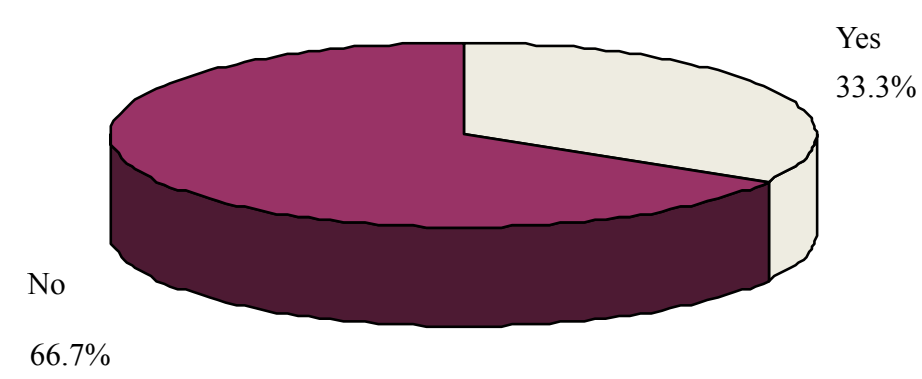

Figure 4. Have you considered other ways of financing the activities of your business? Source: own work based on a survey prepared by the author.

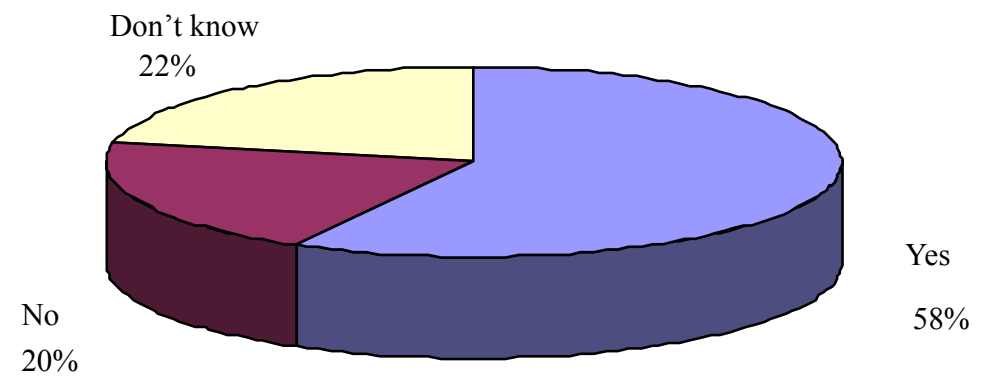

Figure 5. Would you choose a private equity fund as an investor again? Source: own work based on a survey prepared by the author. 
On the other hand, $20 \%$ of dissatisfied entrepreneurs can be considered as a disturbing phenomenon. All the more so that $95 \%$ of respondents stated in their answers to the earlier question regarding the investor's contribution in the company development that without this capital, their company would definitely grow at a slower rate or even go bankrupt. The reason for this may come from conflicts occurring between company managers being also its co-owners. Good relations between partners may in fact be put to the test when the process of the fund leaving the company begins, and the fund itself may be evaluated negatively. An example of this is the conflict between the founders of Lukas Bank and the Enterprise Investors Group's Fund. The disagreement occurred when the fund began the process of disinvestment by selling the company to an industry investor. This encountered enormous opposition from the bank founders. The unclear situation lasted a very long time, but eventually, the transaction with the interested party-Credit Agricole was realised, and the fund's investment in Lukas Bank found a place on the list of the most successful private equity projects in East Central Europe in the years 1990-2003. An argument between the owners occurred also in one of the first Polish courier companies-Stolica S.A.- a moment before its acquisition by UPS Inc. (United Parcel Service, Inc.). Relations deteriorated to such an extent that the company did not participate in one of the surveys conducted at that time, because as the company managers stated - the provided information could have been emotionally charged and would not have been an objective assessment of the fund.

Conflicting situations may also happen when there are problems with achieving the planned financial results. The investor agreement contains forecasts regarding the financial ratios expected by the investor, which the company should achieve within the allotted time period. Expenditure in the initial period of the fund's investment (just after the company receiving the capital) may not produce the desired increases in revenues from sales and the company will reach a weak increase in operating profit or even show a loss. It is frequent that company managers' investment decisions prove to be great mistakes. Previously set strategic objective of the company is not achieved as, for example, investments in new products - the competitive advantage of which has not yet been clearly determined-are commenced. To make matters worse, these products are not introduced into the market despite the enormous cost of making them. An example of this is the attempt of TETA S.A., a company from Wrocław which tried to create a new generation of the ERP (enterprise resource planning) system after entering the Enterprise Investors Company (at the time of making the decision, it already had two such packages in its offer). The investment resulted in a huge financial loss reaching as much as half of the annual turnover, which was never compensated with the revenues from sales of new systems, and the company had to close the project unfinished, as it proved to be too capital intensive.

A common mistake made primarily by partners running a company is the rush to have an impressive headquarters. TETA S.A. may be given as an example in this case as well. The management board of the company first bought land for the construction of a new headquarters (so far nothing has been built there) and shortly afterwards bought a property containing two factory buildings of sizes far exceeding the company's needs. The main building was in a deplorable condition, and its adaptation absorbed huge amounts of money. Moreover, the company itself grew rapidly, employing new, very young, and inexperienced workers (at the time when the investor entered in 1998, the company was employing about 150 people, whereas in mid-2000 - 420 people). There emerged problems with maintaining financial liquidity and the financial results deteriorated. TETA maintained two headquarters as the purchased properties were not suitable for rapid adaptation to office space, and the premises rented by the company until then had become too small. As a result, instead of lowering the cost of headquarter, they drastically raised them. One more element was not taken into 
account - an element especially important in managing a company based on knowledge in $100 \%$. After transferring some of the employees to another place, in their eyes, they became cut off from the command centre - they felt worse than traders and employees of the management board office. Unexpected problems with internal communication started appearing, which significantly deteriorated work performance and the sense of unity with the company. Fuelled with bad employment structure, the crisis was deepening. Relations between experienced staff and the young employees (just out of college) deteriorated rapidly. This affected the management culture, standard of customer service, and the quality of the software and implementation services. The percentage of dissatisfied customers was growing and the company had to focus on mitigating customer complaints. The company's image was severely damaged at that moment. Meetings with a representative of the investor were becoming more frequent and stormier. The conflict between shareholders was growing, but in the end, it was possible to reach agreement. The original owners of the company were sidelined from the current management and became members of the supervisory board. The company's management board currently contains only salaried managers. In this way, ownership relationships were separated from the management. The process of repairing the company's results and improving the effectiveness of its operation lasted several years, until its successful introduction onto the WSE (Warsaw Stock Exchange) in November $2005^{4}$.

Important from the perspective of the role that the fund plays in the functioning of the company is the percentage of shares that it possesses. Primary investments of private equity funds consist in most cases in the purchase of $49 \%$ of the company. The author's studies have shown, however, that subsequent recapitalisation of shareholding companies is frequent ( $70 \%$ of the surveyed companies received more than one tranche of the private equity capital), which significantly increases the level of fund involvement (see Figure 6).

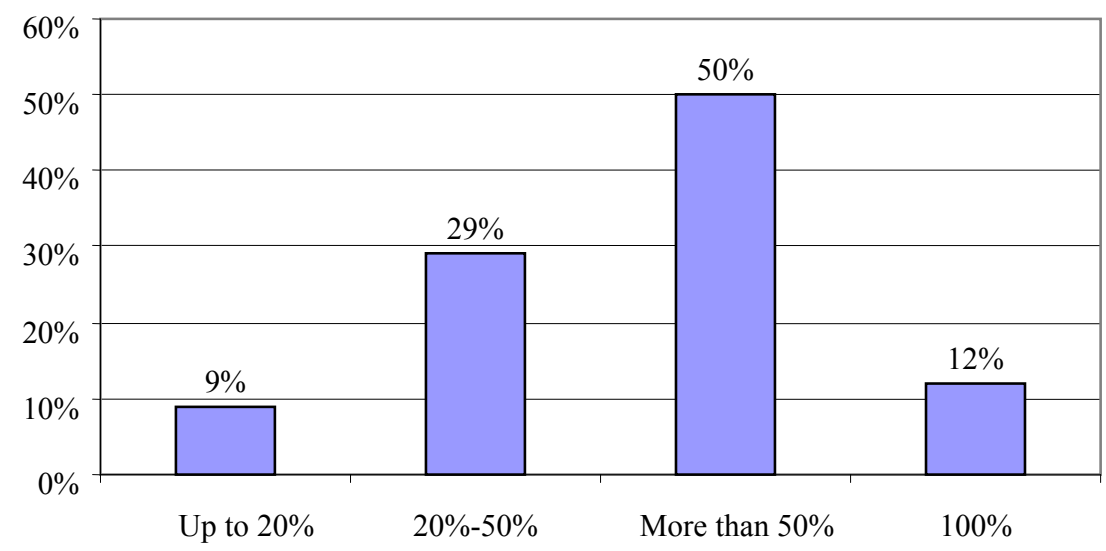

Figure 6. Percentage share of private equity fund in shareholding companies. Source: own work based on a survey prepared by the author.

In the case of $62 \%$ of the surveyed companies, the funds hold more than half of the shares. So they are the majority shareholder, and it is difficult to speak of a passive approach to company management in such cases. Such situation is frequent when the fund buys a company in poor financial condition (e.g., for debt repayment). Restructuring takes place then, and the investor's contribution in the repair of the business is enormous - as it was the case of Fabryka Opakowań Blaszanych Sp. z o.o. from Gdansk. In 1997, a fund managed by Enterprise

${ }^{4}$ Since 2010, TETA S.A. has been part of the Dutch UNIT 4, which holds $100 \%$ of the shares. 
Investors acquired $100 \%$ of shares in a company established on the basis of a state-owned enterprise, previously being under compulsory administration, in exchange for the release from debts. The investor increased the share capital by $\$ 2$ million, providing the company with funds for further restructuring of the company and implementation of the investment programme. Modern management methods and new, not previously used in Poland, technological solutions for the production of cans for the food industry were introduced. By 2000, the volume of production and turnover doubled and production was transferred to a new plant. The total investment exceeded $\$ 15$ million.

Conducted studies indicate that most companies use the capital obtained from private equity funds to increase employment, investments, R\&D (research and development), and export. Over $70 \%$ of the respondents stated that without the fund's involvement, their enterprise would not be able to create new jobs or increase the level of their investments. Also, the fund's contribution in the development of units engaged in R\&D was stated to be significant. Fifty percent of the respondents believe that without the fund's investment, the level of their exports would not increase.

Other mentioned results of private equity's presence in the company include: increased financial liquidity, rapid development of new products, creation of the company's image and brand, employment of highly-skilled workers, and implementation of an information system supporting the cost management and monitoring. In this way, enterprises gain majority of the market and an advantage over the competition. An increase in the company's equity capital enables further improvement of its creditworthiness. It results in greater chances of obtaining additional funding in the form of external capital, which can be designed for additional investments.

\section{Conclusions}

The greatest advantage of a private equity fund as an investor (apart from the capital), therefore consists of generating additional benefits in shareholding enterprises. In this case, additional benefits are understood as managerial knowledge. Fund representatives are experienced managers whose knowledge often comes from having built and run their companies. They regularly assist in building the company strategy and support the management board in selecting the direction of company development which the business should focus its efforts on. It is frequent that they mediate between the management staff and the supervisory board in the exchange of new ideas to help streamline the enterprise's activities. Fund representatives have extensive industry experience and unquestionable management skills backed by accordingly significant financial resources. This gives them an advantage over other financial intermediaries, especially by offering capital to young companies. Despite the fact that activities of a fund representative are usually limited to participation in the supervisory board, the investor implements modern management methods, provides access to a wider portfolio of business relations, and offers strategic advice and assistance in finding valuable employees. In addition, having a fund as an investor increases the company's credibility, thus providing them with alternative possibilities for obtaining further financial resources.

\section{References}

Fałat-Kilijanska, I. (2012). Private equity and the competitiveness of polish enterprises. Oeconomia Copernicana, 1, 89-111.

Gorman, M., \& Salman, W. A. (1989). What do venture capitalists do? Journal of Business Venturing, 4(4), 231-248.

Klaus, N. (2002). Adding value to investment, entrepreneurship education course. Module 7, EVCA, Zavantem, Belgium. Retrieved from http://www.evca.com 
MacMillan, I. C., \& Kulow, D. M. (1988). Corporate ventures into industrial markets: Dynamics of aggressive entry. Journal of Business Venturing, 2(1), 29-39.

Rosentstein, J., Bruno, A. V., Bygrave, V. D., \& Taylor, N. T. (1993). The CEO, venture capitalists and the board. Journal of Business Venturing, 8(2), 99-113.

Rosentstein, J., Bruno, A. V., Bygrave, V. D., \& Taylor, N. T. (1989). Do venture capitalist on boards of portfolio companies add value besides money? Frontiers of Entrepreneurship Research, Babson College, Wellesley, M.A., United States.

Sapienza, H. J., Amason, A. C., \& Manigart, S. (1994). The level and nature of venture capitalists involvement in their portfolio companies: A study of three European countries. Managerial Finance, 20(1), 3-17.

Sapienza, H. J., Manigart, S., \& Vermeir, W. (1994). Venture capitalist governance and value-added in four countries. Journal of Business Venturing, 11(6), 439-469.

Zarządzanie Wartością Firmy. (1999). Orientacja na wzrost wartości wspótczesnego przedsiębiorstwa. In A. Herman and A. Szablewski (Eds.). Warszawa: Poltext. 